\title{
GEOGRAFIA SEM “DESVINCULAÇÕES”: as relações homem-natureza em Conti
}

\author{
geography no "layoff": man-nature relations in Conti
}

Gevson Silva Andrade*

João Paulo Gomes de Vasconcelos Aragão**

\section{RESENHA DE: CONTI, J. B. A Geografia Física e as Relações sociedade/Natureza no Mundo Tropical. São Paulo: Humanitas FFCHL. 2002. 35p.}

Compõe-se o trabalho de Conti (2002) em uma unidade de leitura agradável e direta a respeito do papel da Geografia Física e também da desmistificação do preceito errôneo de que o estudo desta última estaria desvinculado do conhecimento das relações humanas na natureza. $\mathrm{O}$ autor aponta inicialmente uma visão histórica dos caminhos trilhados pela Geografia Física. O mesmo cita Humboldt que, com seus estudos, já incluía dentro da análise geográfica a relação existente entre Hómem e natureza. É destacada ainda, a importância da consciência humana sobre o que são chamadas de espaço agregado por diferentes elementos heterogêneos, unidades geográficas como áreas de relativa homogeneidade e das interações entre sociedade e natureza.

A. Geografia em sua ramificação Física é associada a variáveis como a História e a Cultura. Neste instante faz-se referência ao modo como esta têm sido trabalhada ao longo do tempo, sendo variante, igualmente, pelo comportamento cultural que a manuseia. Fundamentando seu discurso, o autor integra ao seu lastro teórico o pensamento de Milton Santos (1992) e Pierre George (1289) que afinghna a existência de uma Geografia em virtude da presença do Homem na Terra. Apresenta-se ainda Chorley (1973), que argumenta a necessidade de considerar o diálogo entre Homem e Natureza numa perspectiva espacial.

Por outro lado, faz-se uma ressalva consistente sobre a postura determinista que foi direcionada aos geógrafos físicos, gerando nos mesmos o que o autor apresenta como um "complexo de culpa". Sem querer promover maiores embates, é interessante avaliar a resposta dada pelo autor deste texto, apontando como causa deste complexo o desenvolvimento da escola francesa guiada por Vidal De La Blache que teria contribuído, por sua essência cultural e histórica, para criação desta percepção, diga-se de passagem, precipitada e incoerente.

Completando sua análise sobre o incremento do arcabouço teórico da Geografia Física, Conti expõe o pensamento de DAVIS (1898) que enfatiza o papel do Homem no estudo e na compreensão do meio físico, destacando ainda, a valorosa contribuição dos estudos geossistêmicos para consolidação e coerência desta vertente geográfica.

No segundo capítulo de seu trabalho, a noção de trópico é associada a idéia de paisagem circundante. O autor faz uso das noções culturais e sociológica de Levi Strauss (1955) para explicar o conceito de trópico. O mesmo realiza uma associação crítica entre o sistema colonialista com a formação dos trópicos frisando o papel que este último exercera dentro desta afinidade.

(*) Prof. Msc. d a Faculdade de Formação de Professores da Universidade de Pernambuco, Doutorando da Universidade Técnica de Berlin-Alemanha - Rua: Prof ${ }^{\circ}$. Américo Brandão, 43 - Centro, Cep: 55.800-000, Nazaré da Mata/(PE) - Brasil, Tel: (+ 55 81) 3633.4600 - gevson@yahoo.com.br

(**) Mestrando no Programa de Desenvolvimento e Ambiente da Universidade Federal de Pernambuco - Avenida Porfessor Morais Rego, CEP: 50.670-901 - Recife (PE) - Brasil, Tel: (+ 55 81) 21268275 - jp-aragao@bol.com.br/ joaopaulogeo@, hotmail.com 
A partir de então, realiza-se uma análise profunda dos aspectos físicos da zona tropical. $\mathrm{O}$ autor enfatiza a posição da zona tropical em relação às demais no globo terrestre. A distribuição das águas em relação às de terra é propícia à produção de calor. O mosaico climático, por sua vez, seria o principal fruto das contribuições oceânicas à camada atmosférica. Todos estes aspectos seriam fatores otimizadores para produção de paisagens diferenciadas, desde ambientes super úmidos até hiper áridos.

Neste contexto, o pensamento de De Martonne (1946) é destacado para apresentar uma geografia Zonal, derivando desta o então estudo sobre a Geografia dos trópicos.

Incisivo na questão histórica, Conti cita a Carta de pero Vaz de caminha como um dos documentos comprobatórios da maneira como se deu o início da relação entre as comunidades temperadas com os trópicos.

O trabalho "Principes d'une Géografhie Humaine e Economique" de Pierre Gourou (1948) é apontado junto à extensa referência para tratar dos primeiros tratados sobre o mundo tropical. A análise ganha corpo guando o autor direciona sua apreciação à inclusão do Brasil dentro do escopo teórico da Geografia, sobretudo, a partir de 1934 quando da criação na USP do primeiro departamento de Geografia, com a obra de "abre-alas" de Pierre Monbeing "Pionners ET Planteurs de São Paulo", constituindo-se em uma grande inovação para a leitura do espaço geográfico e o dinamismo analítico da Geografia brasileira.

Contempla-se ainda a contribuição de Francis Ruellans (1953) para os estudos em Geomorfologia e, também, do norte-americano Lester King (1956), com sua teoria da pediplanação, cuja importância se faz até hoje incidente para o conhecimento do relevo brasileiro.

Digno de elogios são as memórias citadas pelo autor de grandes pioneiros brasileiros para o estudo da Geografia como Penteado e Silveira que, a partir das décadas de 1940 e 1950, unem-se a um conjunto de personalidades como Ab' Saber para fazer parte da escola brasileira de Geografia.

As conseqüências de uma relação conflituosa como a do ser humano com a natureza são, no quarto capítulo deste texto, discutidas tomando como prisma os exemplos do desmatamento e da desertificação, dois dos principais desequilíbrios ambientais que atingem o meio tropical. Além destas, faz-se referência também a grande concentração populacional existente e a sua irregular distribuição sobre a porção continental.

O autor aponta como principal responsável por estes problemas a atual postura da sociedade, pautada nas relações de produção, dilapiadoras, sobre o meio natural. Esta postura contribui para o aceleramento de processos que antes seriam entendidos como naturais. Nestes casos específicos, o acúmulo de energia proveniente desta faixa tropical permite, ao haverem desequilíbrios, acontecer fortes conseqüências como decomposição das rochas e instabilidade nas encostas.

É neste momento que Conti revela sua principal crítica. Esta se dá ao modelo marxista que pregava como periferias as áreas tropicais, sendo a porção temperada do norte, sobretudo, a Europa, o centro desta relação. A crítica consiste em, contrariamente ao que é colocado pelo marxismo, afirmar que mesmo com o passar dos séculos (século XVII até o século XX), com os avanços tecnológicos e a intensificação da globalização, a realidade geral é a mesma, isto é, o mundo tropical permanece numa posição ainda "periférica" dentro do modelo produção. É neste sentido que o autor propõe uma reflexão: de quem seria culpa por este estado ao qual o mundo tropical encontra-se inserido? A resposta do mesmo: da História e da Economia.

Continuando, ele direciona sua abordagem para as florestas tropicais, lembrando as conferências que promoveram a importância das mesmas: a RIO 92 e a Agenda 21 da ONU. Em contraste a estes movimentos Conti aponta o avanço da devastação citando o Brasil como um dos países mais atingidos. Dentre as conseqüências principais desta realidade são apontados a diminuição de micropartículas advindas da vegetação e, sequentemente, a diminuição das chuvas.

O conceito de desertificação é apresentado como a perda progressiva da produtividade dos 
ecossistemas. As causas apontadas surgem em virtude de atividades como a retirada da vegetação dos solos, erosão acelerada e, por fim, a desertificação.

O mais interessante é a citação do autor que, além dos fatores supracitados, indica também as características culturais e o grau de desenvolvimento econômico das populações. Para tanto o autor faz uso de dados que confirmam que a desertificação é em grande parte uma questão de pobreza.

Por último, uma discussão sobre a perceptividade sobre o espaço tropical é aberta dando à unidade um toque de refino científico. Nesta, o autor discursa que os sentimentos fazem parte da análise espacial e integram deste modo uma das principais vertentes da Geografia da Percepção que possui como sustentáculos reflexivos os ideais de espaço vivido, percebido e imaginário.

A presença do trabalho de Yi Fu Tuan (1980) simboliza a representatividade máxima que é dada a questão quando citado o conceito de Topofilia, que expressa o elo afetivo entre a pessoa e o lugar enquanto postura cultural. Completam esta exposição conceitual o "espaço padrão" e o "espaço contínuo", vistos enquanto categorias representantes, respectivamente, das sociedades indústrias e tropicais, possuindo a primeira, devido a sua maior diversidade perceptiva de espaço vivido, uma maior afetividade na relação sujeito-lugar.

Em suma, a riqueza e a variabilidade simbólico-paisagística dos trópicos são enfatizadas com a citação de trabalhos de estudiosos como Queiroz (1993) em seu "Le Paysan Brésilius ET La Conception dês Étendues" e Laganá (1996) em "Terra Vermelha".

Por fim, destaca-se ainda o papel singular da Geografia enquanto ciência capaz de sintetizar regiões e decodificar ou traduzir as infinitas unidades paisagísticas, sendo sua excelência, a análise sobre as interações entre sociedade e natureza.

Recomenda-se este texto para todos aqueles que estudam a geografia e a vêm enquanto disciplina interdisciplinar, desprovida de ideias antropocêntricas e tão pouco ambientalistas por fundamentação. Tratou-se aqui de uma leitura para aqueles que desejam maiores conhecimentos sobre as relações mútuas e inseparáveis do Homem com sua própria natureza.

Trabalho enviado em julho de 2011

Trabalho aceito em agosto de 2011 